\title{
Outsider and Insider Expertise: The Response of Residents of Deprived Neighbourhoods to an Academic Definition of Social Exclusion
}

\author{
Liz Richardson and Julian Le Grand
}

\section{Contents}

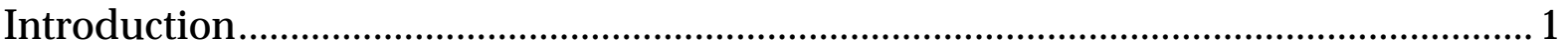

Academic Definitions of Social Exclusion.................................................................. 2

Getting Residents' Responses: Research Methods........................................................ 5

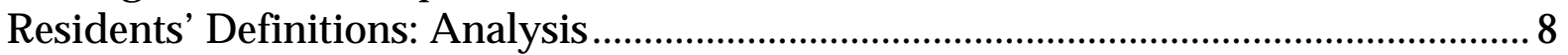

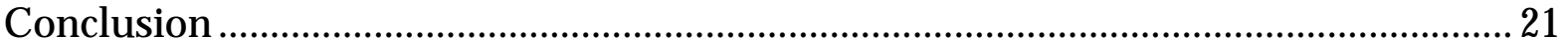

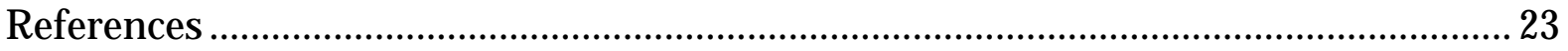

CASEpaper 57

April 2002
Centre for Analysis of Social Exclusion London School of Economics Houghton Street London WC2A 2AE CASE enquiries - tel: 02079556679 


\section{Centre for Analysis of Social Exclusion}

The ESRC Research Centre for Analysis of Social Exclusion (CASE) was established in October 1997 with funding from the Economic and Social Research Council. It is located within the Suntory and Toyota International Centres for Economics and Related Disciplines (STICERD) at the London School of Economics and Political Science, and benefits from support from STICERD. It is directed by Howard Glennerster, John Hills, Kathleen Kiernan, Julian Le Grand, Anne Power and Carol Propper.

Our Discussion Paper series is available free of charge. We also produce summaries of our research in CASEbriefs, and reports from various conferences and activities in CASEreports. To subscribe to the CASEpaper series, or for further information on the work of the Centre and our seminar series, please contact the Centre Administrator, Jane Dickson, on:

$\begin{array}{ll}\text { Telephone: } & \text { UK+20 } 79556679 \\ \text { Fax: } & \text { UK+20 79556951 } \\ \text { Email: } & \text { j.dickson@lse.ac.uk } \\ \text { Web site: } & \text { http://sticerd.lse.ac.uk/Case }\end{array}$

(C) Liz Richardson

Julian Le Grand

All rights reserved. Short sections of text, not to exceed two paragraphs, may be quoted without explicit permission provided that full credit, including () notice, is given to the source. 


\section{Editorial Note and Acknowledgements}

The authors are members of the ESRC Research Centre for Analysis of Social Exclusion, London School of Economics. Liz Richardson is a Research Officer, and Julian Le Grand is a Co-Director, and Richard Titmuss Professor of Health Policy in the LSE's Department of Social Policy. Liz Richardson is grateful to the Gatsby Charitable Foundation for funding. The authors are very grateful to those residents who agreed to participate in the discussions recorded here, and would like to thank Tania Burchardt, John Hills, David Piachaud and Anne Power for comments on an earlier version of this paper.

\section{Abstract}

The aim of this paper is to compare academic interpretations of the term social exclusion with the understanding of people with direct experience of the phenomenon. A pre-selected group of residents of deprived neighbourhoods were asked about various aspects of the concept and their responses compared with the definitions of social exclusion used by Burchardt, Le Grand and Piachaud in their 1999 article in the journal Social Policy and Administration. In general, the residents' understanding of the term corresponded well with the more academic definitions; however, in one or two key areas there were significant differences, for example, the importance of neighbourhood and 'service poverty', and the need for action against aspects of social exclusion on the grounds of social justice. This confirms that it might be useful for more academic concepts to be tested against the views of those with experience of the phenomenon which the concept is trying to capture.

Keywords: definitions of social exclusion; community involvement; neighbourhood renewal

JEL number: I32 


\section{Introduction}

A key part of CASE's activities has been the development and interpretation of the concept of social exclusion. Several CASE publications have concerned themselves with this issue from an academic perspective (including Atkinson, 1998; Barry, 1998; Burchardt, Le Grand and Piachaud, 1999, and Burchardt, Le Grand and Piachaud, forthcoming, 2002a and 2002b). CASE researchers have also been exploring the views of the people directly connected with the experience of exclusion on their understanding of the term. This paper reports on some of that research.

There are two major reasons for including people with experience of social exclusion in discussions of the meaning of the term social exclusion. First, there is a question of legitimacy. If one group of people, such as university academics, impose their own categorisation on another group, such as the 'socially excluded', both those people and others who work in the field, such as local government officers and voluntary sector workers, might have little reason to accept the legitimacy of that categorisation. Indeed they might reject it, arguing that denying the subjects of the debate a voice in it is ironic at best and insulting at worst. Second, and perhaps even more importantly, researchers may miss something significant by not directly consulting the people involved. As we shall see, most operational interpretations of social exclusion involve some assessment of the experience of being socially excluded: and, at the end of the day, the ultimate authority on that has to be those who have directly experienced it.

But there are also obvious problems in trying to involve the 'excluded' in the debate. One is logical in nature: we cannot consult people who are defined as socially excluded until we know who they are, but we cannot know who they are until we know what we mean by social exclusion. Other problems are more practical. How can the research effort be organised so as to get a reliable set of views? How can the social excluded be contacted? When they are, can they or their contacts participate in a debate on equal terms? Would researchers' technical expertise, or other factors such as their class and educational backgrounds, intimidate potential participants? Can the views of those unversed in the ways of academic discourse really be elucidated in such a way as to add anything to what is ultimately a philosophical and scientific issue? 
Part of the purpose of this paper is to show that these problems are far from insuperable. It tries to bridge the divide between a traditional academic approach to the development of conceptual thinking, and participatory action research approaches drawn from the international development field, such as used by the World Bank (Narayan et al, 2000). It reports on group discussions with a panel of 'community experts', people who are residents of low-income social housing areas themselves, who have some experience of social exclusion, however the latter is defined, but who have much wider community links and a representative role for people in their neighbourhoods.

Our discussions concentrated on the validity or otherwise of aspects of the key academic definitions which have been developed in CASE's work in the field. The paper begins with a summary of that work. It then describes the methods employed in setting up and conducting the group discussions. It continues with an analysis of the discussions, comparing the thinking that emerged with the CASE interpretations. The concluding section summarises the analyses and draws out the implications for future work.

\section{Academic Definitions of Social Exclusion}

Social exclusion has been the subject of many attempts at definition. We shall not summarise them all here: a fuller discussion can be found in Burchardt, Le Grand and Piachaud (2002a). Instead, we focus on the reactions of a group of commentators with experience of social exclusion to an operational definition that has been used in empirical research by CASE, and which has formed the starting point for our continuing debates on the concept.

In one of the earliest of CASE's publications, A B Atkinson (1998) pointed to four elements that recur in any discussion of social exclusion: multiple deprivation, relativity, agency and dynamics. In his discussion, multiple deprivation implies that social exclusion is about more than simply income poverty or lack of employment. Other factors are also important, such as absence of community or social interactions. Relativity refers to the fact that people are excluded from a particular society in a particular place at a particular time: there is no 'absolute' social exclusion, whereby some-one can be judged excluded solely by 
reference to his or her circumstances in isolation. The issue of agency arises because exclusion is an act, implying that there are agents who undertake that act. These could be people experiencing aspects of exclusion themselves, in which case the exclusion is voluntary; or, more likely, they are members of the parent society itself, in which case the exclusion is involuntary. The dynamics element arises because exclusion implies not only currently being without a job or income, but also with little prospects for the future.

Tania Burchardt, Julian Le Grand and David Piachaud (1999) incorporated the ideas of multiple deprivation, relativity and agency in their attempt to find a definition of social exclusion that would be useful for empirical work. The proposed definition followed one suggested by one of them (JLG) at an early CASE meeting. This may be phrased as follows: 'An individual is socially excluded if (a) he or she is geographically resident in a society, (b) he or she cannot participate in the normal activities of citizens in that society, and (c) he or she would like to so participate, but is prevented from doing so by factors beyond his or her control'. Conditions (a) and (b) imply relativity; condition (c) emphasises the importance of agency.

A key element of this Burchardt, Le Grand and Piachaud (hereafter BLP) definition involves the interpretation of 'normal' activities. In their early work, published in this Journal (BLP, 1999), they defined five dimensions of normal activity: consumption, savings, production, political and social. In later work (BLP, 2002b) they reduced the number of dimensions to four, including savings activity as a subset of consumption activity. In each case a threshold was defined, below which if an individual or family fell they were to be regarded as socially excluded. The indicators and thresholds used in the later work are shown in Table 1 below.

Of necessity, a definition of a concept tries to explain what is included in the term, and what is out with it. We talk here about people being either 'socially excluded' or not. However, it should be noted that work by CASE which operationalises the concept (e.g. Gardiner and Hills, 1999; Mumford, 2001), including work by the authors of the BLP definition, has uncovered a more fluid picture of people along a continuum of exclusion, rather than a clear division between those who are 'in' and 'out'. 
Table 1: Indicators of Social Exclusion in BLP Definition

\begin{tabular}{ll}
\hline \hline Dimension & Indicator and Threshold \\
\hline Consumption & $\begin{array}{l}\text { Equivalised household net income } \\
\text { under half mean income }\end{array}$ \\
Production & $\begin{array}{l}\text { Not employed or self-employed, in } \\
\text { education or training, looking after } \\
\text { family }\end{array}$ \\
Political engagement & $\begin{array}{l}\text { Non-voter, not a member of } \\
\text { community organisations } \\
\text { Lacks some-one who can offer } \\
\text { personal support }\end{array}$ \\
\hline \hline
\end{tabular}

Now this definition could be challenged on a number of grounds - by people experiencing or working to tackle social exclusion, or by anyone else. One concerns agency. The implication of condition (c) of the BLP definition is that the only form of exclusion that is socially problematic is that which is involuntary and which actually causes the excluded personal distress. Brian Barry (1998) argues that this may be too limiting: that social exclusion is wrong, not because (or not only because) of any personal unhappiness it might create, but because it violates two other values: social justice and social solidarity. Social exclusion stands in the way of equality of opportunity and hence is socially unjust. And it creates fissures in the wider society that are bad for the members of the society on both personal and political levels. This would imply that 'excluded' groups that would not be included under the BLP definition are nonetheless problematic for the wider society: both the very wealthy living in gated communities and confining themselves to the use of private transport, health care and education, and people living in poverty who have created alternative support systems and reject state intervention

There are many other aspects of the BLP definition that could also be challenged. Should the focus be on multiple deprivation or just on poverty or employment? Is it right to emphasise non-participation in socalled 'normal' activities? Are the normal activities themselves properly specified? Is the unit of analysis wrong? Is the definition too individualistic in focus? Should there be more concern with areas or neighbourhoods? 
We shall return to these questions in the next section but one, describing the views of people connected with social exclusion by experience. But first we need to explain our methods.

\section{Getting Residents' Responses: Research Methods}

CASE has an ongoing relationship with an advisory panel for a national community support organisation called Trafford Hall, home of the National Tenants Resource Centre. Trafford Hall provides residential training and small grants to support micro community action and resident empowerment. The advisory panel (known as the Tenant Development Group) was formed in 1991 when the work to develop a national centre for community organisers from disadvantaged neighbourhoods was just beginning.

The task of drawing up a group to act as a representative on behalf of low-income communities was difficult. There was a wide range of different groups representing social housing tenants, including several national bodies. There was much political controversy surrounding council housing, and some community organisations were hostile to tenant management organisations or other newer forms of resident involvement. There was no single focus or mechanism for residents' views to be put across. Many residents and local community leaders were underrepresented in the larger formal structures.

The founders of Trafford Hall held a seminar of representatives from as many bona fide community groups as could be identified. Nominated representatives from national tenants' organisations and smaller local groups attended. The attendees agreed to form a national steering group - the Tenant Development Group - to advise, monitor and represent residents' interests. To guarantee a cross section of all involved, they agreed that local community organisations as well as national bodies could send members as long as they had a track record of serving their neighbourhoods. The Government's new Neighbourhood Renewal Unit has used similar methods to set up its national Community Forum.

In practice, all of the members of the Group are active in their communities in deprived areas. Some have a wider remit to represent deprived communities across larger areas of the UK at a national level. Several of the Group have physical disabilities or limited mobility. Much 
more importantly, they have an overview perspective beyond their personal experience. Some have experienced, or are experiencing, some of the dimensions of exclusion as identified by the BLP definition, such as economic inactivity and low consumption. But, by definition, all the people in the group are not excluded on the political engagement dimension. This is a privileged group in terms of their access to information, links to outside and ability to articulate their views. However, those views are based on direct experience, both their own and that of other residents of low income neighbour hoods who might be excluded on this and other BLP dimensions.

CASE members (including one of the authors, ER) have been involved since the inception of the Tenant Development Group in organising and administering its meetings. The quarterly meetings are primarily to discuss the strategic direction and day-to-day operation of Trafford Hall. But the group are also happy to give their time to help with academic research occasionally, on the grounds that:

[Policy makers and analysts should] "involve grass roots people in the discussions about the solutions and in the solutions" Tenant Development Group member

The Group also feels that talking to resident representatives about issues of social exclusion helps civil servants, academics and government to develop more mutual understanding, and

"begin to understand the reality of life outside of affluence".

Tenant Development Group member

In early 1998, the Government's newly created Social Exclusion Unit asked CASE to organise a workshop with residents, frontline workers in deprived neighbourhoods, and policy makers, to explore what could be done to tackle the problems of difficult estates (Richardson, 1999). This consultation event fed into the SEU's first report, Bringing Britain Together (Social Exclusion Unit, 1998).

It was as a complementary part of this work that we approached the Tenant Development Group to discuss some of our questions about social exclusion. Because of the work done to ensure the widest possible range of community voices on the Group and its representativeness, we felt that this group was an appropriate alternative panel of experts, 
'inside' the experience of social exclusion, but 'outside' the academic debate on the concept, on which to test out our developing ideas.

We ran two discussions, three years apart. 21 residents contributed to the first discussion, and 9 to the second. A core group of 8 resident representatives were present at both discussions. The core group all came from different neighbourhoods, and, in total, they represented 12 different local, regional and national community organisations. A full list of the participants is attached in the Appendix.

The first discussion was in 1998. We focused on the nature and experience of exclusion, whether perceptions mattered, and who or what was affected. The second discussion was in 2001. CASE work and thinking had developed since 1998 and we organised this follow up focus group to explore some of the issues in more detail. We discussed the question of agency, perception in relation to intervention, and what are socially valued activities. We present the two discussions here together, as we have structured the material from the residents into the key issues. The full list of questions from the discussions is presented in Chart 1 below. We did not present the BLP definition or the list of activities as prompts for these discussions. We started from the groups' own direct experiences and those of people they work with, then moved to more abstract thinking about concepts and definitions from there.

The group discussions were conducted with a facilitator from CASE. We took care to ensure that each participant felt able to contribute fully by first asking participants to individually write brief answers to our questions. This allowed everyone to consider their response and prepare their thoughts. We collected the named written responses. We also used this material later to collate our charts and tables. We have presented the material, both written and verbal, as a verbatim account. Where we have added text for clarity we have used [ ].

After getting the written responses, we opened up the discussion to the group, using the named written responses as prompts to encourage quieter members to contribute to the discussion. We asked questions that started by drawing on people's direct experiences. This both grounded people's views in their experience, and helped people feel confident about making a contribution. The discussions fleshed out people's views, and have the group a chance to debate, challenge and add to each other's arguments. We also used brainstorming techniques 
to gather ideas in a non-threatening way. A ground rule of brainstorming is that participants cannot challenge others' ideas.

\section{Chart 1: Questions asked in the discussions}

\section{Session 1. February 1998}

1. Are you affected by social exclusion? How does it affect you or someone that you know?

2. Who or what is affected by social exclusion?

3. Is social exclusion a state of mind?

4. If you were the head of the Social Exclusion Unit, what would you do to tackle social exclusion?

\section{Session 2. March 2001}

1. What activities or experiences do you think people should be able to participate in to be considered socially included?

2. Give three examples of someone who is socially excluded for reasons beyond their control, and three examples of someone who is socially excluded voluntarily.

3. Should we do something about someone who is socially excluded, but who is not personally distressed about their situation?

4. Have things got better worse or stayed the same since the last focus group in February 1998?

\section{Residents' Definitions: Analysis}

As noted at the end of the previous section but one, the BLP interpretation of social exclusion could be challenged in a number of ways. These included: the focus on multiple deprivation, the role of participation, the definition of normal activities, the role of agency, and the individualistic focus. Accordingly we have divided our analysis of the group discussions under these headings. However, we begin with an essential preliminary to any discussion of the area: with growing national prosperity, is social exclusion still a problem?

\section{The Continuing Importance of Social Exclusion}

The overwhelming feeling of the group discussions was that social exclusion did affect the participants: their families, their communities and their estates:

"Social exclusion affects everyone, people and area, old and young". 
The group pointed to a range of problems that affected them personally and most directly: stigma; transport and mobility; age; facilities and services; crime and drugs; family life, income and employment. Their responses are illustrated in Chart 2 below.

\section{Chart 2: Residents' Views: how social exclusion affects residents and their neighbourhoods}

Q: Are you affected by social exclusion? How does it affect you or someone that you know?

Stigma and service neglect

"Different areas who get a bit of a bad name is made to sound 10 times worse than it is."

"Yes [I am affected by social exclusion], by stigmatising the area in which I live

"How am I affected? My estate was called one of the 'worst estates', but these estates aren't usually as bad as they are made out. It was called the forgotten estate because the landlord ignored it"

\section{Low income and family problems}

"Yes, the residents we work with [are affected by social exclusion] e.g., low wage earners, children who have been excluded from school. They often truant because they are kept at home to child mind, especially for mothers who are working on the sly and so can't ask for help."

Age, mobility and insecurity

"Yes, it affects me and my elderly parent who has no money, not very mobile, their sheltered scheme too far out of main centre, afraid to go out after dark."

\section{Crime and youth disaffection}

"Yes my area [is affected] because of crime and poor people i.e. young children, youth, no employment, old people."

"Yes! Low income, unemployment. Fear of possible crime, drugs."

In the second discussion in 2001, the group pointed out that

"employment in certain areas has improved. But the gap between rich and poor has got worse." 
Other research by CASE on the trajectories of twelve severely disadvantaged areas, and neighbourhoods within those areas backs up these perceptions (Lupton, 2001). This study has found that despite growing national prosperity, problems of social exclusion in areas of concentrated deprivation are diminishing, but less rapidly than in surrounding areas. Some issues, particularly substance misuse, are said by residents and workers across agencies to be worsening.

\section{Multiple Deprivation and Dynamics}

A core element of the BLP definition on social exclusion is that it is about more than income and employment. The residents' direct experience led them to make a similar point. They pointed out that the 'working poor', not just people out of work, face problems. They also understood that the issue of low income is broader than the question of employment. Also, they argued that income was a means to quality of life, rather than as an end in itself

"It affects people through low incomes, unemployment, and
deprivation from a social life available when industry was
abundant in the area."

Others emphasised that the problem in some areas was not unemployment, but people on low incomes within employment, and the gap between the value of wages and the cost of living:

"it's people just on the poverty line, who get 50p too much to qualify for benefits, so they are not counted as being socially excluded, but they miss out on things, like free training."

"When I was working, I was struggling, but they seem to class only those on benefits as socially excluded, they assume that if you aren't on benefits you got no problems."

Not only is social exclusion about more than income, the residents saw that the multiple elements also interrelate. People felt that the problems, and the solutions were interlinked:

"One follows from another, you can't disentangle them."

Another feature of exclusion in the early CASE work by Atkinson was that it is a dynamic process; peoples' circumstances change over time. 
The group also highlighted the dynamic and changing nature of exclusionary processes.

"[I am affected by social exclusion] by being caught in a poverty trap, by being disabled and unable to work. With no hope in hell of getting out of it."

This presents a challenge to the BLP definition and its operationalisation as it currently does not directly incorporate the dynamic aspects of exclusion.

\section{Participation}

The BLP definition has as the core idea the lack of opportunities to participate: 'an individual is socially excluded if he or she cannot participate in normal activities...' The residents supported this core concept. Chart 1 shows the residents' descriptions of examples of social exclusion outcomes, written in response to the question 'Are you affected by social exclusion? How does it affect you or someone that you know?' During the verbal discussion that followed the written exercise, the group pulled together these examples into a definition of social exclusion, summed up as:

"not being able to play a full part in the activities that others can."

In discussion, the group made it clear that being able to do the same kinds of activities as others in society was key, as with the BLP definition. For example, income was valued not for its own sake but as a means to an end of participating in a standard of leisure and social interaction others enjoy. One mother said in the first discussion:

"as a single parent I do feel affected. My children cannot join a lot of the clubs they would love to. The only reason for this is my income is so low I can't give them the money they need. Even a night at the cinema for me and three children, with one drink $\mathcal{E}$ sweets each, cost approx. E20. This is a quarter of my weekly income. I know my children need to go out to places to learn social skills."

Another participant in the second discussion defined the term as "having the chance to let your children be able to take up sport, dancing, and other activities even when on benefits." 
Three years on, the group participants were still happy with the idea that somebody could be considered to be socially included if they could participate in 'normal' activities

"[Social exclusion is an] inability to safely participate in outside activities due to disability (motability), or similar due to financial shortage."

As with the BLP definition, a person is defined with reference to the standards of mainstream society - however controversial this is to define.

"It's about participating in normal society, but it depends on your definition - what is normal society?"

Those who chose to engage in alternatives to mainstream society, such as young people in a youth gang are still seen as socially excluded. A gang may give opportunities for social interaction but not in a socially respected/valued way. For instance, a youth gang

"may not be happy, really; they are bolstering each other - it's mutual support for hardships."

and therefore cannot be considered an equivalent alternative for participation in mainstream society.

\section{Normal Activities}

The BLP definition covers four dimensions of life that people need to have the opportunity to participate in order to be a full member of society: consumption, production, political engagement, and social interaction. In the second discussion, the residents expanded on the core definition with a list of what they considered to be socially valued activities. All the participants were asked to contribute short written notes on the key socially valued activities which we collated verbatim into this table. The activities are listed in Chart 3 under the headings of the four dimensions identified in the BLP definition, plus an Other category. 
Chart 3: Residents' Views: activities people should be able to participate in to be considered socially included

\begin{tabular}{|c|c|}
\hline Consumption & $\begin{array}{l}\text { Have enough money for food } \\
\text { Have a decent home/affordable home } \\
\text { Home address } \\
\text { Get childcare or general care facilities } \\
\text { Amenities for their children } \\
\text { Be able to obtain credit } \\
\text { Access to public services* } \\
\text { Proper schooling* } \\
\text { Decent education* } \\
\text { Be educated to the capacity required* } \\
\text { Decent health service* } \\
\text { Get medical help immediately required } \\
\text { Repairs properly done* } \\
\text { Insecurity* } \\
\text { Lack of protection from intruders* } \\
\text { Enjoy your home without interruption from noise, } \\
\text { harassment* } \\
\text { Transport in rural areas* } \\
\text { Be able to afford transport costs* } \\
\text { Lack of community facilities* }\end{array}$ \\
\hline Production & $\begin{array}{l}\text { Employment } \\
\text { Work } \\
\text { Get a job } \\
\text { Earn a living }\end{array}$ \\
\hline Political Engagement & $\begin{array}{l}\text { Be involved in the community } \\
\text { To be accepted as having useful ideas to contribute to a } \\
\text { society } \\
\text { Have access to information from the local authority }\end{array}$ \\
\hline Social Interaction & Join in sporting activities \\
\hline Other & $\begin{array}{l}\text { Lack of education - unable to communicate } \\
\text { Be able to communicate both verbally and in writing } \\
\text { Be able to learn new skills } \\
\text { Access training } \\
\text { Not to be discriminated against }\end{array}$ \\
\hline
\end{tabular}

* = consumption of publicly provided goods and services

There are two main points that emerge from this list. First, the residents list communication skills and ability to learn as a key activity in its own right. These skills link to people's ability or opportunity to participate across all four dimensions, e.g. by engaging politically, interacting socially, working, caring or volunteering, and consuming. For the 
residents communication skills are a generic set of skills that is a determining factor in opportunities to participate across a range of dimensions. In the BLP definition, these aspects would be counted more properly as factors affecting social exclusion - factors that contribute to the risk that someone becomes socially excluded - rather than the phenomenon itself. It is not clear that the residents would accept this distinction; for them inability to communicate is itself a manifestation of social exclusion, as well as a cause.

The second issue raised by the residents' list relates to the consumption of publicly funded and provided services - such as health, education and transport - and the consumption of public goods - such as a safe neighbourhood environment. These are traditional concerns of residents' organisations, particularly in disadvantaged neighbourhoods.

In the BLP definition such factors could be included under the heading of consumption. After all, public services and public goods are consumed/experienced by individuals. However, they have special qualities that make them different from other types of goods and services people use their purchasing power to consume (e.g. clothes and electrical goods). Some communal problems such as a litter strewn physical environment, a negative neighbourhood reputation, or high crime neighbourhood are extremely difficult to buy one's way out of without moving out of the area. There is, of course, a range of solutions open to the individual resident, such as buying home security systems, joining a private health care scheme/BUPA etc. However, while individual purchasing power can buy in alternatives or supplements to public services/goods, it cannot easily be used to obtain better public goods, or better public services themselves. Different mechanisms need to be applied to change the quality of communal life or the quality of the local school. Hence, overall, it seems better to add the consumption or experience of these good and service as the fifth dimension of normal activities in the BLP definition rather than incorporate them with private purchases under a general heading of consumption. This also fits with the idea of 'service poverty' used in a major piece of authoritative research to investigate the nature and extent of poverty and social exclusion in Britain in the 1990s (Gordon et al., 2000).

\section{The Role of Agency}

The group participants agreed that there was an important distinction between those who were at least partly responsible for their exclusion, 
and those who were excluded due to factors beyond their control. For example, a person with a criminal record was seen by the group as socially excluded, but 'through choice' because

"it's their fault they committed the offence in the first place."

We asked the resident to give written examples of socially excluded people in both categories - socially excluded for reasons beyond their control, and socially excluded 'from choice'. These are summarised in Chart 4.

The group discussed some of the problems associated with making the distinction between voluntary and involuntary behaviour. For example, in the case of substance misuse, they argued that initially the person could be said to be excluding themselves partly out of choice, but, after they become addicted, the exclusion/problems they face are more beyond their control.
"It's peoples' choice to become addicted."
"It's debatable, it's their choice to get in, but once they are addicted it may be beyond their control."

There may be mitigating circumstances for a person's behaviour, or complex trade offs made by people trying to secure a better quality of life for themselves and their families.

"There's truancy because they keep them at home to child mind, especially people working on the sly - they can't ask for help."

The residents argued that there is a clear distinction between social exclusion and what Barry (1998) has termed 'social isolation' e.g. wealthy families living in gated communities in USA. They referred to social isolation as "withdrawal". The group were critical of better-off individuals who engaged in forms of withdrawal from the wider society. Their experience is that some middle class communities "want to be cut off". One resident told of a private estate in their neighbourhood where the owner-occupiers had tried to get a footpath changed so other people would be discouraged from walking through the area. "There's a Mason Dixon line between the areas". 
Chart 4: Residents' Views: examples of people socially excluded for reasons beyond their control or from choice

\begin{tabular}{|c|c|}
\hline Beyond Control & From Choice \\
\hline $\begin{array}{l}\text { Family problems } \\
\text { Family break up and homeless } \\
\text { (divorce) } \\
\text { Lone parents (family commitments) } \\
\text { Incompatibility between parent and } \\
\text { child } \\
\text { Housing problems } \\
\text { People who live in poor houses } \\
\text { (council) } \\
\text { Poor - low wage in poor housing } \\
\text { Homeless } \\
\text { Health problems } \\
\text { People with learning disabilities } \\
\text { People with mental health problems } \\
\text { People with mental illness } \\
\text { Ill health had to give up work } \\
\text { Unable to join in society for medical } \\
\text { reasons } \\
\text { Disabled } \\
\text { Suffering from an addiction, drugs or } \\
\text { alcohol, which has caused loss of job, } \\
\text { income, home and respect of their } \\
\text { peers } \\
\text { Loss of work and low skill } \\
\text { Unemployed } \\
\text { Unemployment (finance) } \\
\text { Low wages (which restricts) } \\
\text { Poor having } \\
\text { People who lose their jobs } \\
\text { Made redundant } \\
\text { No confidence } \\
\text { Lack of schooling } \\
\text { Made redundant, } \\
\text { transferable skills, therefore need to } \\
\text { acquire new ones }\end{array}$ & $\begin{array}{l}\text { Health } \\
\text { Smokers } \\
\text { Work and training incentives } \\
\text { People who don't want to work } \\
\text { Benefit fraud, no address } \\
\text { Rent arrears } \\
\text { People who won't take the opportunities } \\
\text { given to them } \\
\text { Not willing to learn } \\
\text { Laziness } \\
\text { Lazy gave up work/sacked } \\
\text { Won't work because benefits higher than } \\
\text { wages } \\
\text { Crime and substance misuse } \\
\text { Prisoners } \\
\text { Criminals } \\
\text { Committed crime sent to prison } \\
\text { Drug takers } \\
\text { Drug addicts } \\
\text { Thrown out of family because chose a life } \\
\text { of drug taking } \\
\text { Chose to become a drifter } \\
\text { Anti social behaviour } \\
\text { Criminal action or convictions (depending } \\
\text { on the crime) }\end{array}$ \\
\hline $\begin{array}{l}\text { Discrimination } \\
\text { Black people } \\
\text { Colour or race }\end{array}$ & \\
\hline
\end{tabular}


It is implicit in the BLP definition that people who voluntarily exclude themselves are unproblematic for the wider society. The residents disagreed. They felt that any person experiencing exclusion (whether they have had a hand in it or not) also caused wider society a problem in terms of the threat such divisions pose to social solidarity. While the group distinguished between the voluntary withdrawal by better off individuals and the voluntary social exclusion of people facing disadvantage, such as through benefit fraud or criminal activity, they were critical of both types of divisive outcome.

Exclusion by peers due to prejudice or misunderstanding was frowned on by the residents, e.g.

"sometimes children are excluded by other children because they don't fit in."

But, in some cases, peer support to exclude another resident was considered to be acceptable. In particular, they felt that a community might have to support social landlords and local authorities to exclude people who were socially disruptive.

Other work at CASE (Power and Mumford, 1999) indicates that it is common to find resident support for the enforcement of societally acceptable rules of behaviour, i.e. participation in mainstream society. This is the route to social inclusion. So, in areas of social housing when there is an infraction of these rules, many residents argue strongly that the 'anti-social' resident should be evicted by the social landlord.

Such cases could be seen, not as involuntary social exclusion, but as 'through choice'. A resident behaving in an extremely disruptive way who is then evicted is considered to have voluntarily opted out of participating in the norms of society and is not being excluded so much as excluding themselves. The clause in the BLP definition, "for reasons beyond [the person's] control", could be said to support the argument that people who are evicted are partly choosing to opt out. Therefore, it could be argued that resident support for eviction of people guilty of anti-social behaviour is not 'the excluded excluding others'. Instead it is a marginal group trying to protect (often fragile) neighbourhood conditions and guard against further social exclusion. The group advocated a punitive approach to disruptive behaviours in the context of a strong social support system, for example: 
"if I was Tony Blair? I'd make them sort out the anti-social problems. We're making them [the local authority] set up after hours support for victims."

"Council to enforce by laws. A clean person makes clean living."

A somewhat different question was raised about the four dimensions of social exclusion, whether there should be a difference in our attitudes towards voluntary non-participation in the political engagement dimension as opposed to the other three dimensions. The definition gives equal weight to each of the four dimensions. However, the residents argued that:

"Food is a necessity but if people chose not to vote then it's their choice."

The group recognised the possible restrictions on people's opportunities to participate in a democratic process

"They need to understand what they're doing - it takes sufficient education."

"It's choice through ignorance."

"Who the party is in Government doesn't make a lot of difference to the majority."

"There are $58 \%$ disillusioned non voters."

Despite these limits, they argued for the importance of political engagement

"It is important for people to have the opportunity to have a say.".

"If candidates for local and national elections aren't challenged you get bad decision making."

"The only power ordinary people have is in their numbers - so if people don't come forward then it's a problem."

"We are still suffering from the 1980s - 'there is no such thing as society'. It takes a long time to changes cultures, cultures of individualism. Some are excluding themselves without knowing it 
because they try and go it alone but without the resources to look after themselves."

Overall, therefore, it would seem as though, in the residents' view, nonparticipation in the political dimension is (a) important and (b) not always (or very often) voluntary. Both of these positions are consistent with the BLP definition.

Finally, what of the situation where people are not choosing to be socially excluded, but they are reconciled to their situation, i.e. 'poor but happy'? The BLP definition is based on the implicit premise that it is not possible to define people as socially excluded without their consent. Some residents agreed, disliking the way that categories are imposed on people anyway, regardless of insiders' perceptions. We asked, 'Is social exclusion a state of mind?'

"Yes, [people are defined as socially excluded] by society at large, even if not by the community."

"Some people are looked down on when they are in the poverty trap. This shouldn't be."

"When I was working, I was struggling. I was counted as socially excluded, but I didn't think I was at the time."

Further, this could affect whether and how to intervene.

"Yes, [an isolated, but happy OAP on a state pension] is socially excluded, but you can't force them to accept help, especially if they don't think they need it - all you can do is offer."

However, others disagreed with this. They felt that we could impose a definition based on objective criteria

"Yes [even if you are happy/reject the label], you're socially excluded from many aspects of life i.e. try to get a bank account."

"Yes, if you're happy and poor you can still be socially excluded."

Moreover, they felt it was desirable for agencies like Government to take action about social exclusion, almost regardless of the actual feelings of the individuals or the families involved. We asked 'Should we do 
something about someone who is socially excluded, but who is not personally distressed about their situation?' The majority said yes. In support of this position they gave reasons such as the following:

"To raise expectations."

"They are still part of the community."

"Yes, we must be bothered because if there is a deterioration of their function it could be a worse problem both financially and physically but discretion is needed."

"We should ensure that they are happy, not just making do! They should be enabled to make educated choices."

"Yes, because they are still part of the community and the human race, but show respect for the person's choice."

"No one is an island."

"We should be concerned but to keep a watching brief respecting their wishes."

These views are consistent with the challenge to the BLP position provided by Brian Barry's work on social justice, discussed earlier.

\section{Individuals and Areas}

An important point made in the discussion concerns the relative importance of individuals versus the area in which he or she lives. We asked the group in the first discussion, 'Who or what is affected by social exclusion?' The residents argued that certain 'area effects' such as tenure concentrations overrode individual situations. One of the residents illustrated this point by saying:

"A council house tenant winning the lottery would still be socially excluded."

Someone else pointed out that:

"Sometimes areas are excluded but a lot of the people in them aren't." 
The group felt strongly that social exclusion affected both individuals and areas, and that there were independent area effects and processes at work:

"Both people and the area [are affected by social exclusion] through lack of local shops, transport, facilities and jobs."

"It is whole areas - in some places people refuse to deliver, even the local free paper which has local events free and charged, local jobs, local voluntary services are also advertised in it. This does not reach the people who need them the most."

"Whole areas can be and are socially excluded."

"Both [areas and individuals can be socially excluded]. A few years back there was a big uproar because employers were getting applications from the estate and throwing them straight in the bin. The job centre was doing it too, they would send you for the low paid jobs if you were from..."

"People and areas are affected. Some of the catalogue companies are refusing to deliver to some parts of London as they are considered high risk, no-go areas."

"Communities can be socially excluded or towns even."

The central critique that the residents' comments provide is with the unit of analysis used in the BLP definition. It starts "an individual is socially excluded if...". The residents are all active in community based organisations, which indicates the value they place on geographically based communities and services. They deal with neighbourhood level issues; they have an 'area' perspective as well as an individual one. They tackle service failure and are focused on particular geographical neighbourhoods or areas of deprivation and the interaction of the processes of social exclusion in those neighbourhoods.

\section{Conclusion}

Overall, the core of the BLP definition that social exclusion is about participation in socially valued activities stood up pretty well to its test against the views of the resident representatives. Its emphases on multiple deprivation and on relativity were fully endorsed by the 
residents. The residents did present the current BLP definition with the challenge of incorporating the idea of process. The four dimensions of normal activities were also endorsed, although an additional one was added: the consumption of public services and public goods.

The residents also agreed that agency was important. However, relatively few of them accepted the view implicit in the BLP definition that the voluntary social exclusion and/or social withdrawal was not a problem; in particular, they saw real difficulties in the better-off isolating themselves. Nor did they feel that all forms of social exclusion created wholly problematic outcomes, arguing that on occasion a society had a legitimate right to protect itself by excluding its more anti-social members.

There were two others areas where the views of the residents did not coincide with the BLP definition. First, the residents placed much more emphasis on the need for intervention to tackle social exclusion problems on the grounds of social justice and social solidarity than is implied by the BLP position. Second, they did not like the definition's heavy focus on the individual and would have welcomed a definition that could also embrace the concept of areas and neighbourhoods being excluded.

The LSE has a longstanding tradition of active connections between research and policy and practice. In this research we wanted to combine the 'outsider' expertise of CASE with the 'insider' expertise of people most directly connected with the experience of social exclusion. We also wanted to connect the closed 'insiders' academic world to the life experiences of resident 'outsiders'. We believe that the result has been fruitful, leading to significant changes in our thinking about the concept of social exclusion, particularly around the concept of 'service exclusion' and the inclusion of an area perspective - changes that will be reflected in our future research and that we hope may also be of assistance to others working in the area. 


\section{References}

Atkinson, A.B. (1998) "Social exclusion, poverty and unemployment" in A.B. Atkinson and J. Hills (eds) Exclusion, Employment and Opportunity. CASEpaper 4. London: CASE, London School of Economics.

Barry, B. (1998) Social Exclusion, Social Isolation and the Distribution of Income CASEpaper 12. London: CASE, London School of Economics. Forthcoming as Ch. 2 in Hills J., Le Grand, J. and Piachaud, D. (eds) Understanding Social Exclusion Oxford: Oxford University Press.

Burchardt, T., Le Grand, J., and Piachaud, D. (1999) "Social exclusion in Britain 1991-1995" Social Policy and Administration, 33 (3): 227-244.

Burchardt, T., Le Grand, J., and Piachaud, D. (2002a) 'Introduction', Ch.1 in Hills J., Le Grand, J. and Piachaud, D. (eds) Understanding Social Exclusion. Oxford: Oxford University Press.

Burchardt, T., Le Grand, J., and Piachaud, D. (2002b) 'Degrees of exclusion: developing a dynamic, multi-dimensional measure', Ch.3 in Hills J., Le Grand, J. and Piachaud, D. (eds) Understanding Social Exclusion. Oxford: Oxford University Press.

Gardiner, K. and Hills, J. (1999) "Policy implications of new data on income mobility" The Economic Journal, 109 (453): 91-111.

Gordon et al. (2000) Poverty and Social Exclusion in Britain York: Joseph Rowntree Foundation.

Lupton, R. (2001) Places Apart? The Initial Report of CASE's Areas Study CASEreport 14. London: CASE, London School of Economics.

Mumford, K. (2001) Talking to Families in East London: a report on the first stage of the research CASEreport 9. London: CASE, London School of Economics.

Narayan, D., Chambers, R., Shah, M.K., and Petesch, P. (2000) Voices of the Poor: Crying Out for Change Oxford: Oxford University Press.

Power, A., and Mumford, K. (1999) The Slow Death of Great Cities? Urban Abandonment or Urban Renaissance York: Joseph Rowntree Foundation. 
Power, A. (1995) Trafford Hall: a brief history of the National Tenants Resource Centre 1987-1995 Chester: National Tenants Resource Centre.

Richardson, E. (1999) Tackling Difficult Estates CASEreport 4. London: CASE, London School of Economics.

Richardson, E. and Mumford, K. (forthcoming) "Community, neighbourhood and social infrastructure" in Hills J., Le Grand, J. and Piachaud, D. Understanding Social Exclusion Oxford: Oxford University Press

Social Exclusion Unit (1998). Bringing Britain Together: a National Strategy for Neighbourhood Renewal. London: HMSO. 


\section{Appendix: List of participants}

\begin{tabular}{|c|c|c|}
\hline Name & Organisation/s - memberships past and present & Area \\
\hline Mike Bailey & $\begin{array}{l}\text { South Hampstead Housing Co-op and the National } \\
\text { Federation of Tenant Management Organisations } \\
\text { (TMOs) }\end{array}$ & London \\
\hline Mike Berry & $\begin{array}{l}\text { Runcorn Tenants' Federation and Tenant Participation } \\
\text { Advisory Service (TPAS England) Management } \\
\text { Committee }\end{array}$ & Runcorn \\
\hline Ken Bray* & $\begin{array}{l}\text { Liverpool High Rise Tenants' Group } \\
\text { InterHAT Alliance (Housing Action Trusts) }\end{array}$ & Liverpool \\
\hline Alf Brimmings & Shirehampton Area Housing Committee & Bristol \\
\hline Lynne Britton & $\begin{array}{l}\text { Redbrick Tenants' \& Residents' Association and } \\
\text { Canning Town SRB Partnership Board }\end{array}$ & London \\
\hline Francis Burrows & $\begin{array}{l}\text { Greatwood \& Horseclose Residents' Association } \\
\text { Tenant Director of Trafford Hall, home of the National } \\
\text { Tenants Resource Centre }\end{array}$ & Skipton \\
\hline Cora Carter* & $\begin{array}{l}\text { Cowlersley Tenants' and Residents' Association } \\
\text { Kirklees Tenants' Federation } \\
\text { TPAS England Management Committee } \\
\text { Tenant and Resident Organisations of England } \\
\text { (TAROE) }\end{array}$ & Huddersfield \\
\hline Bobby Cockell & Greatwood \& Horseclose Residents' Association & Skipton \\
\hline William Davies & $\begin{array}{l}\text { Brymbo Tenants' and Residents' Association } \\
\text { Wrexham Tenants' Federation }\end{array}$ & Wrexham \\
\hline Joanne Jackson & Mansfield Welfare Rights Project & Mansfield \\
\hline Bryan Martin & Fishponds Area Housing Committee & Bristol \\
\hline $\begin{array}{l}\text { Donna } \\
\text { McCormack }\end{array}$ & Liverpool Mediation Service & Liverpool \\
\hline Eric Moore* & $\begin{array}{l}\text { Johnstown Residents' Association } \\
\text { Wrexham Tenants' Federation } \\
\text { TPAS Wales Management Committee } \\
\text { Welsh Tenants' Federation }\end{array}$ & Wrexham \\
\hline Alan Parker & $\begin{array}{l}\text { Windmill Hill Residents' Association } \\
\text { Windmill Hill Community Forum }\end{array}$ & Runcorn \\
\hline Lynn Peacock & Botcherby Residents Action Group & Carlisle \\
\hline Cliff Powell* & Fairways Tenants' and Residents' Association & Mansfield \\
\hline Cath Quine* & $\begin{array}{l}\text { Digmoor Estate Management Board } \\
\text { National Federation of TMOs }\end{array}$ & Skelmersdale \\
\hline Elaine Rendell & $\begin{array}{l}\text { Freehold EMB } \\
\text { Federation of Estate Management Boards (now } \\
\text { National Federation of TMOs) }\end{array}$ & Rochdale \\
\hline Sammy Rice & Liverpool High Rise Tenants' Group & Liverpool \\
\hline Isabella Vint* & $\begin{array}{l}\text { Mansfield Welfare Rights Project } \\
\text { Garibaldi and Newlands Residents' Association } \\
\text { National Tenants' and Residents' Federation (now } \\
\text { TAROE) }\end{array}$ & Mansfield \\
\hline
\end{tabular}




\begin{tabular}{|l|l|l|}
\hline Name & Organisation/s - memberships past and present & Area \\
\hline Cliff Whiteley* $^{*}$ & $\begin{array}{l}\text { Waterloo/Cottage Homes Tenants' and Residents' Ass. } \\
\text { Kirklees Tenants' Federation } \\
\text { TPAS England Management Committee } \\
\text { Tenant and Resident Organisations of England } \\
\text { (TAROE) }\end{array}$ & \\
\hline
\end{tabular}

${ }^{*}=$ present for both discussions 